\title{
Thoughts on the Open Education and Teaching Evaluation in Higher Vocational Colleges
}

\author{
Changying Wang \\ Shaanxi Vocational \& Technical College \\ Xi'an, Shaanxi, 710100 \\ e-mail: 362195607@qq.com
}

\begin{abstract}
The higher vocational education has the dual attributes: higher education and vocational education. To build a modern higher vocational education system, it's required not only to realize the school-enterprise combination and producing-teaching integration in teaching mode, teaching method and teaching content but also to establish a new education and teaching evaluation system to evaluate and lead the transformation. Meanwhile innovations of the subject, content, process and index of evaluation shall be made to the open education and teaching evaluation system in higher vocational colleges.
\end{abstract}

Keywords-higher vocational colleges; open education; teaching evaluation

\section{PRESENT CONDITIONS OF THE EDUCATION AND TEACHING EVALUATION IN HIGHER VOCATIONAL COLLEGES}

In the foreign teaching supervision and evaluation system, generally, the educational investors and school are the subjects of quality supervision and evaluation. The representative higher vocational colleges in developed countries, such as the technical colleges and vocational colleges in German, community colleges in America, polytechnics in England, short-term technical colleges and senior technician classes in France, etc., all have been operated under the supervision of educational investors, and moreover, along with the impeccable vocational qualification certificate system as guarantee, are able to effectively assume responsibility for the educational objects. From the prospective of the method of vocational education and teaching quality supervision and evaluation, some countries have adopted the national vocational qualification attestation examination, such as the TAFE (Technical and Further Education) college system in Australian. In terms of the object and content of vocational education and teaching quality supervision and evaluation, in France, the entire education system has been regarded as the evaluation object and the educational management, teaching, discipline, specialty, course construction, goal of college development, planning of school reform, teachers and students have been regarded as the evaluation content. It is thus clear that the foreign higher vocational education and teaching quality supervision and evaluation system can be divided into three levels which are related to each other and relatively independent: government - society- school.

In China, the learning and implementation of supervision and evaluation over higher vocational education and teaching quality was started late and a complete and mature system has not been formed yet. The random teaching inspection organized by government education department mostly has been taken as the supervision and evaluation over higher vocational education and teaching quality, which promotes the improvement of teaching quality by external pressure and lacks the internal self-restricting mechanism as well as internal complete, institutionalized and normalized teaching quality guarantee system. Lots of higher vocational institutions have inaccurate cultivation targeting in the actual operation, putting undue emphasis on the systematicness of discipline and failing to follow the "essential and enough" principle, thereby resulting in the unconspicuous characteristics of higher vocational education which are: excessive theoretical depth, lagging vocational technical standard and insufficient degree of vocational combination. The existence of undergraduate compression-type higher vocational education mode has led to the following problems in the higher vocational teaching quality supervision and guarantee system: uncomprehensive supervision and evaluation over teaching process and teaching content, parochialism of the subjects of evaluation. Most of existing higher vocational colleges usually lay particular stress on classroom teaching during the supervision over teaching process while little attention has been paid to the supervision and evaluation over experiment, practice, filed training and other teaching links and steps, which makes the teaching quality supervision and evaluation unable to effectively guide the vocational education direction. Currently, many higher vocational colleges are continuously improving their own teaching quality evaluation system but they pay more attention to the student-oriented evaluation as well as peer evaluation and supervisor evaluation which are all self-evaluation limited to the internal school. The subject of evaluation is too closed and little or even no importance has been attached to the absorption of social industries' (enterprises' and departments') participation, thereby causing the professionalism and objectivity absence in the 
establishment of practical teaching supervision and evaluation system and moreover causing the divorce between closed evaluation mechanism and regional economic development so that the local economy can not be effectively served and the education and teaching management can not be scientifically guided.

\section{FUNCTIONS OF THE OPEN EDUCATION AND TEACHING EVALUATION}

The education and teaching evaluation is designed to evaluate teachers, students, teaching content, teaching method, teaching environment, teaching management and other factors in teaching process, aiming to realize the correcting, inspiring and guiding functions through supervision, diagnosis and feedback. The main evaluation methods include quantitative evaluation and qualitative evaluation. By education and teaching evaluation, we can get the whole picture of education and teaching work condition and then use the diagnosis, feedback, rectification and other methods to improve the educational management and teaching work, arouse teachers' enthusiasm to work, promote their sustainable development, enhance their teaching ability and facilitate their realization of self values. The education and teaching evaluation is a crucial mechanism to improve the teaching quality.

The open education and teaching evaluation is a management activity performed based on the theories of humanistic management, which, according to the discriminated advantages of traditional evaluation and the introduction of social participation, experimental and practical training content as well as industrial standard in the subject, content, process and index of evaluation, evaluates teachers, students, teaching content, teaching method, teaching environment, teaching management and other factors in teaching process with comprehensive, multi-subject-based and real-time evaluation method, so as to assume a completely open posture in the realization of integration of vocational colleges and society and to accelerate the modernization of higher vocational education.

The role of the open education and teaching evaluation specifically is played in:

\section{A. To carry out the school running policy of vocational education in teaching management}

Education and teaching evaluation is an important work for vocational school to carry out educational policy, improve the quality of education, and cultivate qualified talents.

Several Opinions of the Ministry of Education on Promoting the Higher Vocational Education Reform and Innovation to Lead Vocational Education's Scientific Development (JZC [2011]No.12) points out: “......Higher vocational education has double attribute of higher education and vocational education with the main task of develop high-skilled talents in the first line of production, construction, service, and management. We must persist in service-aiming and employment-orientation, and take the school running policy of the development path of the combination of production, teaching and research......" Since the task of higher vocational education is to serve the needs of society, and personnel employment, it must first accept the evaluation of service object. Only when the education teaching evaluation that social parties participate in is introduced, can we timely discover that higher vocational education is not consistent with the pattern of economic development and industrial structure adjustment through the subject of the open education teaching evaluation, so scientific and reasonable adjustment of training objectives, professional Settings, teaching contents, and teaching methods, can better implement the shool running policy of the vocational education in the education teaching management.

\section{B. To promote the teaching reform of higher vocational education to strengthen the Education teaching evaluation of practical training}

Education teaching evaluation means to make judgment of the value of educational and teaching activities, and the judgment should not only use modern education ideas, but also require evaluation content, evaluation standard and methods to meet the needs of the educational and teaching reform.. On the basis of the regional industry development's demand for talents, with clear talents training objectives, China's higher vocational education reform deepens the personnel training mode reform of the integration of work and study, school-enterprise cooperation, and substituted post exercitation. In this reform, the teaching content and teaching methods, teaching management and teaching resources are facing a revolution. Numerous historical experience has shown that if there is no a set of comprehensive education teaching evaluation system, and scientific education teaching evaluation methods do not be taken, the educational and teaching reform must inevitably be struggling. To realize the modernization of vocational education, the traditional classroom evaluation must be expanded to the experiment, training and practice. Only by strengthen the education teaching evaluation of practice training, can we complete the main task of high skilled talents in the first line of production, construction, service, and management, and really promote the educational and teaching reform of higher vocational education.

\section{To strengthen scientific management of teachers, and inspire their enthusiasm for work}

The traditional education and teaching evaluation weights discrimination and selection, much more emphasizes on learning outcome than process, and more emphasizes on inside school than out of school, and its subject and method of "evaluation" is single, which make s most of the evaluated teachers become the losers monitored by evaluators, and dampens their enthusiasm. 
Open education teaching evaluation will make evaluation process dynamic and take teachers into account of evaluation subject, which makes the problems in the education teaching work to be discovered and solved in time, and makes teachers' passive monitored state be changed into the state of actively promoting the work, so as to stimulate the work enthusiasm, which has very important significance in promoting the modernization of higher vocational education.

\section{To promote the integration of production and education, and shool-enterprise cooperation to modernize vocational education.}

To create a modern system of higher vocational education, work content and requirements of vocational education teaching must be closely integrated with regional economy together, and work out the professional talent training scheme with the industry (enterprises) to achieve the docking of professional and industry (enterprise) post; To carry out "double certificates" system, the connection of professional course content and professional standards shall be achieved; To introduce new technology, new process, schools shall cooperate with enterprises to jointly develop the professional courses and teaching resources. Open education teaching evaluation index to guide the education teaching content changes, so as to promote the fusion, between production and education cooperation, realize the modern vocational education.

\section{THE APPROACHES OF THE OPEN EDUCATION AND TEACHING EVALUATION}

$\mathrm{Lu}$ Xin, a deputy minister of education, on March 22, 2014, attending the "China Development Forum in 2014", elaborates on promoting the establishment of modern vocational education system and other issues. $\mathrm{Lu}$ Xin thinks the basic characteristics of the system are mainly embodied in five aspects. First is to make the employment as the guidance, especially the good service to youth employment. The second is the establishment of systematic technical skill talent cultivation system. The third is to make the integration of production and education, and school-enterprise cooperation throughout the entire process of system construction. The fourth is to build an open talent growth overpass which is interchange, and can achieve the cohesion of inside and outside, in order to open the door to success for the majority of young people. The last is to fully play the market role and fully mobilize social resources.

To realize the modernization of vocational education, education and teaching work must be adjusted at any time education according to the requirements of social economy, and it is necessary to strengthen the industry guidance, deepen the enterprise participation, making vocational education more responsive to industry needs and vocational needs. With the popularization of higher education, higher vocational colleges scale expands gradually, and the number of college admissions increases rapidly, thereby resulting in a series of problems: lack of college education resources, inadequate educational condition, more part-time teachers, and thus the education quality can not be effectively guaranteed. In order to realize the sustainable development of higher vocational education, and the modernization, we must proceed from the demand of the society and vocational education to establish comprehensive opening diversified teaching evaluation concept, and revise our long-held, closed, deep-rooted view of knowledge, teaching and learning. The subject of higher vocational teaching evaluation shall be expanded from closed to fully opening, the content of the higher vocational teaching evaluation expanded from classroom teaching to practice teaching, higher vocational teaching evaluation process expanded from the terminal evaluation to process evaluation, and higher vocational teaching evaluation indexes expanded from the single evaluation to diversified evaluation, thereby truly realizing the modernization of higher vocational education.

\section{A. Open subject of evaluation}

A system require to continually exchange energy with the external to maintain the stability of the system itself, and the openness of the system is the lifeline of the system. Information collection and feedback of higher vocational education and teaching evaluation is only confined to internal college, lack of comprehensiveness and science of evaluation. We should cover the society, and industries and enterprises into the evaluation subject, improve the teaching quality evaluation system, strengthen the industry guidance, and deepen the enterprise participation, thus making the vocational education more responsive to industry needs and professional needs, and truly achieve the integration of production and education, and school-enterprise cooperation. In addition, the previous evaluation focuses on on-way evaluation of managers of teachers, and ignores the objective factors of the evaluated, which is lack of the objectivity of the evaluation and improvement. Therefore, the introduction of self-evaluation of teachers and the evaluation of teaching resources and teaching management can more objectively reflect the influence factors of education results, and have more effective supervision and rectification.

Open subject of evaluation: supervisors, department, teaching and research office, teachers, students, industries and enterprises, superiors, parents, and social persons.

- Supervisors. Supervisor office is an independent teaching evaluation department, and supervisors are school full-time teachers with senior titles, hired outside education experts and senior engineers of industries and enterprises, who are responsible for the supervision and evaluation of the whole school education teaching situation.

- Department. The department evaluation is mainly performed by supervisors group of the department, to supervise and evaluate the department teaching work. 
- Teaching and research office. For the department evaluation, mainly the director of the department of teaching and research office and professional leaders are responsible for the professional construction evaluation, adhering to the employment-oriented professional construction.

- Teachers. Teachers can carry our the evaluation of peers, can monitor and evaluate students' study condition, can make self-evaluation of the whole teaching process. And teachers can conduct the evaluation of the providing information of infrastructure, faculty's teaching resources and teaching aids, which can ensure teaching activities normal and orderly. Finally, teachers can monitor and evaluate the work attitude of service and the ability of the college teaching administration department.

- Students. Students can evaluate teacher's classroom teaching, practice teaching, as well as teaching resources, and teaching management.

- Industries and enterprises. Employers are the direct subject to accept graduates trained by college, and can directly evaluate the quality of talent training from the angle of job occupation, such as employment ability of students, school curriculum and training target, etc..

- Society. Social persons can put forward the evaluation of school spirit and training goal.

- Parents. Parents can put forward their opinions and views about the school education teaching quality of service, and have the right to supervise and evaluate the teaching process and the quality of talents training.

- Superior. The administrative departments of education shall monitor the implementation of national education policy and the policy's situation, according to legal procedures and standards, conduct an independent, objective and fair evaluation for higher vocational colleges.

\section{B. Open evaluation contents}

The National mid and long-term reform and development Plan (2010-2020) states: "The development of vocational education is an important way to promote economic development, stimulate employment, improve people's livelihood, and to solve the problem of "agriculture, rural areas and farmers", which is key to relieve the contradictions of labor supply and demand structure, and must be placed in a more prominent position". The principle of higher vocational education teaching work is student-oriented to improve the students' employment ability. Therefore, how to create a good teaching environment and how to improve teachers' teaching ability and teaching effect, are the ultimate goal of school management. To achieve this goal, we must open the evaluation contents, which means to make teaching process, teaching management and teaching resources into the evaluation scope. Previous education and teaching evaluation often evaluates teachers' teaching process, but ignores the cultivation of the students' practical ability. Previous quality of teaching standard construction of professional construction, course construction and teaching focuses on the classroom teaching quality monitoring, and practical teaching and professional ability training are lack of strong guarantee. In order to realize the modernization of vocational education, we must strengthen the practicality, openness and occupational of teaching process, therefore strengthening the evaluation of practical teaching is an important manifestation of evaluation contents openness.

\section{Open evaluation process}

Closely based on improving the teaching quality, higher vocational education teaching evaluation should fully reflect the modern education thoughts and ideas, adhere to the people-oriented, deepen teaching reform, and improve the focus of the quality of teaching focus from results to the whole process of quality, from a single quality evaluation to the process of quality management, from divided quality control measures to the systematic and comprehensive quality management. The traditional education and teaching evaluation weights discrimination and selection, much more emphasizes on learning outcome than process, and the evaluation results emphasizes on discrimination not improvement. Open education and teaching evaluation make evaluation process dynamic, and make full use the advantages of network remote sharing, making evaluation subject anytime and anywhere can evaluate the evaluation object and feedback. And the computer terminal can timely issue warning signal according to the evaluation to make the quality of the single evaluation into the process management of quality, thus ensuring the virtuous cycle and self-healing of college education teaching works. In 1980, American evaluation experts Kuba and Lincoln put forwards "the evaluation is to give value to the evaluated things, and it is essentially a kind of psychological construction". This theory has been positioned as the fourth generation of evaluation theory, which emphasizes the "response" and "negotiation" is an important symbol of the evaluation, and the evaluation is stakeholders' reconstruction of reality, a process of creation. Only the dynamic real-time evaluation can better achieve the "creative process".

\section{Open evaluation index}

Famous managerialist Chen Yi'an professor put the essence of humanistic management and highest standards into three sentences: light up the glory of the human nature, return to the value of life, and create prosperity and happiness. In the management of the organization, only by doing the perfect integration of all three, we can more comprehensively embody goals and objectives of humanistic management.

- Diversified evaluation index. The combination of subjective evaluation and objective evaluation, and the combination of quantitative evaluation and descriptive evaluation can provide development platform for 
different types of teachers to form their own style, so that every worker can gain a sense of accomplishment, and inspire their creativity, creating the modernization of higher vocational education.

- The design of the open education and teaching evaluation index. Through various evaluation information, we can understand the status of the economic development and professional standards change, adjust the evaluation index at any time, and timely guide the reform of education teaching contents, so as to promote the integration of production and education, and school-enterprise cooperation, truly achieving the modernization of the vocational education.

\section{ACKNOWLEDGMENT}

Project name: Research and Practice of the Teaching Quality Supervision and Evaluation System in Shaanxi Vocational \& Technical College

Project No.: Gj1321

\section{REFERENCES}

[1] Li Zemin. The Current Situation of Teaching Supervision in Colleges and Universities and Development Survey Report [J]. Journal of Guangdong Institute of Education, 2004 (4)

[2] Zhou Maodong. Discussion of Improving Teaching Supervision System in Higher Vocational Colleges [J]. China Higher Education Research, 2005 (6)

[3] Li Li. The Innovation and Theory Thinking OF University Teaching Supervision Monitoring System [J]. Journal of Education and Profession, 2009 (4)

[4] James Nolan, Jr, Teachers' Supervision and Evaluation [US] China Light Industry Press, March, 2007 first edition

[5] Pan Yongqing, Sun Wenbin, Lu Jimin. Effective Mechanism of Multivariate Evaluation Innovation Education, Shandong Education Press, 2005, first edition

[6] Wang Hanlan. Education Evaluation, Henan University Press, November 1995, the 1 st edition

[7] Jiang Fenghua. Modern Education Evaluation, Guangdong People's Publishing House, August 2003, the 3rd edition

[8] He Zhaohua. General Education Evaluation Study Shaanxi People's Publishing House, November 1992, the 1st edition 